\title{
THREE NEW SPECIES OF CALANDRINIA (PORTULACACEAE) FROM INLAND AUSTRALIA
}

\author{
Syeda SALeha TAHIR* \\ (Accepted for publication 4.12.1979)
}

\section{ABSTRACT}

Syeda, Saleha Tahir (John Ray Herbarium, University of Sydney, Australia, 2006) 1980. Three new species of Calandrinia (Portulacaceae) from inland Australia. Telopea $2(I)$ : 59-61.-Calandrinia reticulata, C. papillata and C. porifera are described as new species.

\section{INTRODUCTION}

I have examined all herbarium specimens of Calandrinia located in the State Herbaria of Australia during a review of the genus in Australia. In addition I have examined type specimens or photographs of types of all species described to date except those which were destroyed in Vienna and Berlin during the last war. It has become clear that at least three undescribed species occur within the boundaries of the proposed Central Australian Flora. These are described here.

\section{Calandrinia porifera Syeda, sp. nov.}

Herba carnosa scapis numerosis $3-9 \mathrm{~cm}$ longis. Petala 5, obovata usque anguste elliptica $0.8-2.0 \mathrm{~cm}$ longa. Stigmata 4 usque ad bases libera. Capsula obpyriformis poro terminali dehiscens.

Holotype: Cundeelee Mission east of Kalgoorlie and north of T.A. railway, P. Boswell C36, Spring 1967 (PERTH).

The specific epithet refers to the poricidal dehiscence of the capsule.

Succulent herb with numerous scapes $3-9 \mathrm{~cm}$ long arising from the basal tuft of leaves. Leaves many at the base in a tuft as well as on the upper part of the scapes, obovate to orbicular, $1.0-3.5 \mathrm{~mm}$ long, $1.0-1.3 \mathrm{~mm}$ wide, subsessile, opposite or alternate. Flowers in monochasia; pedicel spreading, 3-5 mm long; bracts opposite, scarious, acuminate, $0.5-1.1 \mathrm{~mm}$ long, $0.4-0.5 \mathrm{~mm}$ wide. Sepals orbicular to broadovate, obtuse, $1.5-2.0 \mathrm{~mm}$ long, $2.0-2.5 \mathrm{~mm}$ wide, thin. Petals 5, obovate to narrowelliptic, $0.8-2.0 \mathrm{~mm}$ long, $0.4-1.0 \mathrm{~mm}$ wide. Stamens $5-7$; filaments united at the base to form a ring around the base of the ovary, adnate to the petals at the base, $0.5-1.0 \mathrm{~mm}$ long; anthers ovate-oblong, versatile, $0.2-0.4 \mathrm{~mm}$ long, $0.1-0.2 \mathrm{~mm}$ wide. Ovary globular, translucent, $0.5-0.9 \mathrm{~mm}$ diam.; stigmata 4 , free to the base, $0.2-$ $0.4 \mathrm{~mm}$ long; ovules c. 10, attached to the unbranched placenta. Capsule obpyriform, as long as the sepals or a little longer, opening by a pore at the top. Seeds c. 10, ovoid, red-brown, colliculate, glossy, c. $0.3 \mathrm{~mm}$ long, $0.2 \mathrm{~mm}$ wide.

This species differs from all others in Australia except C. disperma J. M. Black, and $C$. papillata Syeda, in that the capsule opens through a terminal pore. The capsule of $C$. disperma, however, is very swollen at the base, where a single seed is contained. In the narrow-attenuate upper part another slightly longer and narrower seed is held. Moreover, the rim of the pore is surmounted by minute teeth in $C$. disperma. A comparison with $C$. papillata is made under that species in this contribution.

The species is known only from the type locality.

\footnotetext{
* Present address: Botany Department, University of Sind, Jamshore, Pakistan.
} 


\section{Calandrinia reticulata Syeda, sp. nov.}

Herba carnosa. Caules basilares ramosi unusquisque fasciculum foliorum et scapas plures $8-24 \mathrm{~cm}$ longas ferens. Petala 5 obovata usque ad elliptica $7-8 \mathrm{~mm}$ longa. Stamina numerosa. Stigmata 3 libera usque ad bases. Capsula ovoidea 3 valvis dehiscens. Semina reticulata c. $0.2 \mathrm{~mm}$ diam.

Holoty PE: Simpsons Gap National Park, Northern Territory, P. K. Latz 4895, 18.4.1974 (NT 43058).

The specific epithet refers to the characteristic pattern on the surface of the seed.

Succulent herb with basal stems erect, up to $3 \mathrm{~cm}$ high and branching, with each branch bearing a fascicle of leaves. Scapes 1-3 or more on each stem, axillary, 8-24 cm long, leafless and bearing a few flowers near the top. Leaves linear to linear-lanceolate or oblanceolate, $2-6 \mathrm{~cm}$ long, $1.5-5.5 \mathrm{~mm}$ wide, sessile. Flowers few in monochasia on a \pm erect peduncle; pedicels $0.5-2 \mathrm{~cm}$ long; bracts opposite, scarious, acute, $1-1.5 \mathrm{~mm}$ long. Sepals very broad-ovate, 4-5 mm long, $5-6 \mathrm{~mm}$ wide, herbaceous. Petals 5 , obovate to elliptic or spathulate, $7-10 \mathrm{~mm}$ long, $3-5.5 \mathrm{~mm}$ wide, pink-purple. Stamens numerous $(>10)$ in two or three groups; filaments of unequal length, connate at the base and adnate to the base of the petals; anthers oblong-ovate, versatile, $0.4-0.7 \mathrm{~mm}$ long, $0.3-0.4 \mathrm{~mm}$ wide. Ovary subglobular, whitish-brown, translucent, $2-2.5 \mathrm{~mm}$ diam.; stigmata 3 , free to the base, linear, red-brown, $1.4 \mathrm{~mm}$ long. Ovules numerous $(>10)$, reniform, $0.1-0.4 \mathrm{~mm}$ long attached to a branched placenta. Capsule, ovoid with an erect pedicel, light brown and with a smooth shining surface, a little longer than the sepals, 3-valved to the base. Seeds numerous, red-brown, glossy, reticulate, $0.2 \mathrm{~mm}$ diam.

This species differs from all others in Australia in possessing reticulate seeds. It is probably closest to $C$. remota J. M. Black, which has a glossy, almost smooth seed.

Specimens Examined: Northern Territory: Woodlands Station Shearing Shed, T. L. Setter 325, 9.9.1973 (PERTH); 29 miles [46 km] S. of Alice Springs, G. Chippendale, i1.11.1954 (BRI 004895); 4 miles [6.5 km] N. of Mt Swan Station, R. A. Perry 333l, 12.3.1953 (NT 20021); 13 miles [21 km] S. of Angas Downs Homestead, G. Chippendale, 24.11.1954 (NT 624). Western Australia: Lawlers, F. H. Hamu 8.1902 (BRI 88069).

\section{Calandrinia papillata Syeda, sp. nov.}

Herba carnosa scapis pluribus 10-35 $\mathrm{cm}$ longis in axillis foliorum basilarium dispositis. Folia linearia usque ad oblanceolata $8-55 \mathrm{~mm}$ longa. Flores in monochasiis bracteatis dispositi. Petala 7-9, anguste oblanceolata usque ad obovata 9-18 $\mathrm{mm}$ long. Stamina numerosa. Stigmata 4 usque ad bases libera. Capsula poro terminali valvis brevissimis dehiscens. Semina papillata c. $0.25 \mathrm{~mm}$ diametro.

HoLotyPE: Davis Creck, Lycus River, Western Australia, C. A. Gardner 6105, 25.9.1941 (PERTH).

Succulent herb with scapes several and up to $35 \mathrm{~cm}$ long, arising from the axils of the basal leaves. Leaves cauline and basal, alternate or 2-4 at each node, sessile or nearly so, linear to oblanceolate, $8-55 \mathrm{~mm}$ long, 2-6 $\mathrm{mm}$ wide. Flowers arranged in monochasia; pedicels spreading, 5-22 mm long; bracts opposite, scarious or sometimes leafy, $2.5-4 \mathrm{~mm}$ long. Sepals ovate, thin, 5-6 $\mathrm{mm}$ long, $3.5-5.5 \mathrm{~mm}$ wide. Petals 7-9, narrow-oblanceolate to obovate, $9-18 \mathrm{~mm}$ iong, $2-5.5 \mathrm{~mm}$ wide, pink. Stamens numerous $(>10) ;$ filaments of unequal length, connate into a membranous cup around the base of the ovary, c. $6 \mathrm{~mm}$ long; anthers oblong, $0.5-0.8 \mathrm{~mm}$ long, $0.3-0.4 \mathrm{~mm}$ wide. Ovary ovoid, $2.5-3.5 \mathrm{~mm}$ long; stigmata 4, free to the base, linear, $2.5-7 \mathrm{~mm}$ long; ovules numerous $(>10)$, attached to a branched placenta. Capsule, conical, brown to dark brown, dehiscing through a pore at the top and occasionally split into 4 valves at the summit, as long as or slightly longer than the sepals. Seeds numerous $(>10)$, red-brown, matt, reniform, c. $0.25 \mathrm{~mm}$ long, papillate. 
This species is close to $C$. porifera Syeda from which it differs in sometimes having 4 very short valves to the capsule, larger petals, and most clearly in the papillate seeds.

Specimens Examined: Western Australia: $24 \mathrm{~km}$ S. of Woodlands Station on WoodlandsMt Clere Road, T. L. Setter 40I, 7.10.1973 (PERTH); Belele Station WNW. of Meekatharra, $D$. $W$. Goodall $3286,6.11 .1965$ (PERTH): $21 \mathrm{~km}$ from Mt Magnet on Geraldton Road. $Y$. Chadwick 1988, 16.10.1963 (PERTH).

\section{ACKNOWLEDGEMENTS}

I wish to thank Professor R. C. Carolin, Dr S. W. L. Jacobs and my husband, M. T. M. Rajput, for help during the work associated with this contribution.

Manuscript received 5.9.1979 